ARTICLE

\title{
Visible-light-mediated catalyst-free synthesis of unnatural $\alpha$-amino acids and peptide macrocycles
}

Mengran Wang ${ }^{1,6}$, Chao Wang ${ }^{1,6}$, Yumei Huo ${ }^{1}$, Xiaobo Dang ${ }^{1}$, Hongxiang Xue ${ }^{2}$, Liangyu Liu ${ }^{3}$, Hongli Chai ${ }^{1}$, Xiuling Xie ${ }^{1}$, Zhixuan $\mathrm{Li}^{3}$, Doudou $\mathrm{Lu}^{2} \&$ Zhaoqing Xu (1) ${ }^{1,4,5 凶}$

The visible light induced, photocatalysts or photoabsorbing EDA complexes mediated cleavage of pyridinium $\mathrm{C}-\mathrm{N}$ bond were reported in the past years. Here, we report an ionic compound promote homolytic cleavage of pyridinium $\mathrm{C}-\mathrm{N}$ bond by exploiting the photonic energy from visible light. This finding is successfully applied in deaminative hydroalkylation of a series of alkenes including naturally occurring dehydroalanine, which provides an efficient way to prepare $\beta$-alkyl substituted unnatural amino acids under mild and photocatalyst-free conditions. Importantly, by using this protocol, the deaminative cyclization of peptide backbone $\mathrm{N}$-terminals is realized. Furthermore, the use of $\mathrm{Et}_{3} \mathrm{~N}$ or $\mathrm{PPh}_{3}$ as reductants and $\mathrm{H}_{2} \mathrm{O}$ as hydrogen atom source is a practical advantage. We anticipate that our protocol will be useful in peptide synthesis and modern peptide drug discovery.

\footnotetext{
${ }^{1}$ Key Laboratory of Preclinical Study for New Drugs of Gansu Province, School of Basic Medical Science, Lanzhou University, Lanzhou 730000, China. ${ }^{2}$ Institute of Biochemistry and Molecular Biology, School of Life Sciences, Lanzhou University, Lanzhou 730000, China. ${ }^{3}$ School of Pharmacy, Lanzhou University, Lanzhou 730000, China. ${ }^{4}$ Research Unit of Peptide Science, Chinese Academy of Medical Sciences, 2019RU066, Lanzhou 730000, China. ${ }^{5}$ Key Laboratory of Dental Maxillofacial Reconstruction and Biological Intelligence Manufacturing, Gansu Province, Lanzhou University, Lanzhou 730000, China.

${ }^{6}$ These authors contributed equally: Mengran Wang, Chao Wang. ${ }^{凶}$ email: zqxu@lzu.edu.cn
} 
eptides are indispensable bioactive components for exerting biological function normally in various cells. Thus, therapeutic peptide is deemed to be an exquisite substitution of an endogenous molecule which possesses high affinity and selectivity against a pharmacologically diverse set of biological targets $^{1,2}$. Although remarkable achievements have been made in peptide research, poor membrane permeability, low metabolic resistance, and bioavailability still are insurmountable barriers to endogenous bioactive peptide therapeutic ${ }^{3}$. In this context, several methods have been developed and applied to solve these problems, such as incorporation of unnatural amino acids (UAAs) or macrocyclizations of linear peptides ${ }^{4}$.

In recent years, with the rapid development of photochemistry, visible light promoted radical coupling reactions have become important pathway for building chemical bonds ${ }^{5}$. Owing to mild reaction conditions and excellent functional group tolerance, photoinduced chemical transformations provided an excellent strategy for chemoselective biomolecule modification, which are widely applied in the modification of amino acids, peptides, and proteins $^{6-12}$. The modification of amino acids is an important strategy for preparing UAAs, such as the modification of glycine, cysteine, tyrosine, tryptophan, histidine, etc. Dehydroalanine (Dha) is a naturally occurring amino acid ${ }^{13,14}$, and also can be easily prepared from Ser, Cys, and selenocystein, which is preinserted at the position of interest in peptides and proteins ${ }^{15,16}$. In recent years, Dha has been used as a versatile backbone for synthesis of UAAs. Although these methods provided efficient ways for preparation of various UAAs, the accessing of $\beta$-alkyl substituted UAAs were still limited, and the reactions required either transition metal catalysts or stoichiometric amount of metal reagents ${ }^{17-32}$. Furthermore, the compatible methods for modification of Dha unit in peptides are still rare $^{33,34}$, and the related peptide cyclization protocol based on functionalization of Dha is still underdeveloped.

The traditional peptide cyclization methods are based on lactamization and disulfide bond formation. In the past decades, with the advent of new generations of peptide pharmaceuticals, varying the nature of ring-forming linkage in peptide macrocycles became a necessity ${ }^{35}$. In this context, transition metal-catalyzed peptide macrocyclization strategies are gaining increasing popularity, and include $\mathrm{C}-\mathrm{H}$ activation, oxidative cross-couplings, heteroatom ligation, and radical reactions, etc ${ }^{36-39}$. MacMillan and co-workers recently reported a visible-light-promoted decarboxylative Giese reaction, which provided an efficient way for macrocyclization of peptide backbone $C$-terminal in an alternative manner besides lactam bond (Fig. 1a) ${ }^{40,41}$.

Primary amines are naturally occurring and chemically diverse starting materials, and deaminative reaction of primary amines has emerged as an important strategy for generating alkyl radicals. Katritzky salts derived from $\alpha-1^{\circ}$ and $\alpha-2^{\circ}$ amines, as well as imines derived from sterically encumbered $\alpha-3^{\circ}$ primary amines are important alkyl radical precusors ${ }^{42,43}$. In line with our interests in photocatalysis and peptide synthesis ${ }^{44-46}$, we here report a visible light induced, ionic compounds promoted $\mathrm{C}-\mathrm{N}$ cleavage of Katritzky salts, which is successfully used in the preparation of $\beta$-alkyl substituted UAAs and macrocyclization of peptide. Notably, $\mathrm{Et}_{3} \mathrm{~N}$ and $\mathrm{PPh}_{3}$ are effective to act as singleelectron reductants for the reactions.

\section{Results}

Design plan. The Katritzky-type alkyl substituted pyridinium (1) can generate an alkyl radical through a photoinduced dissociative electron transfer ${ }^{47}$. However, the light absorption of alkyl a
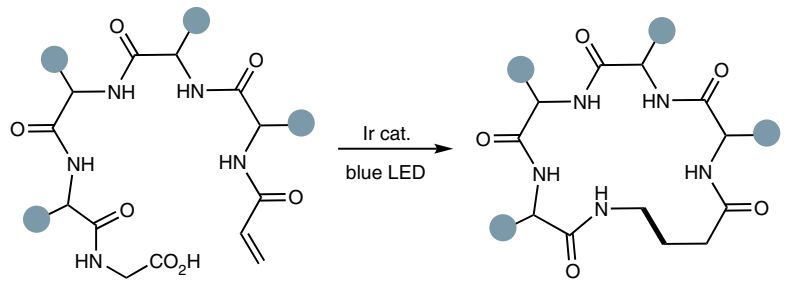

b

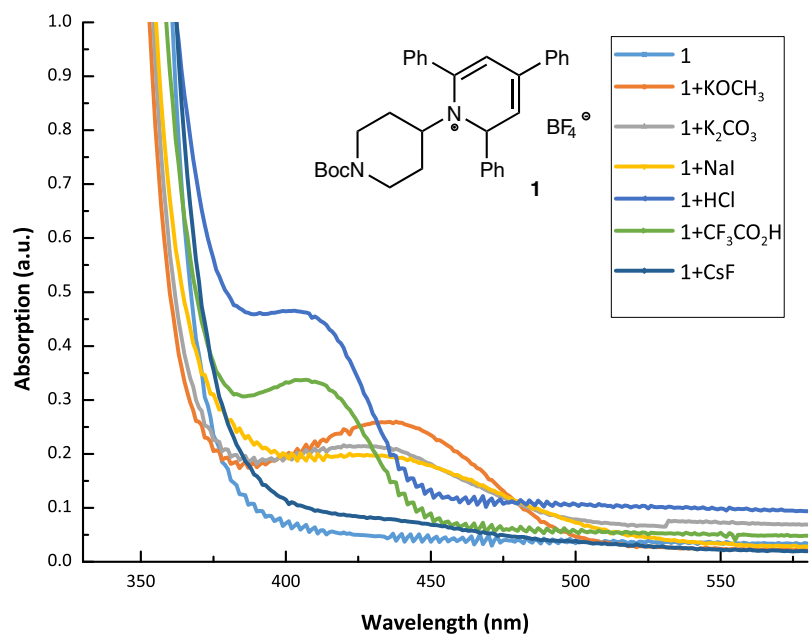

c
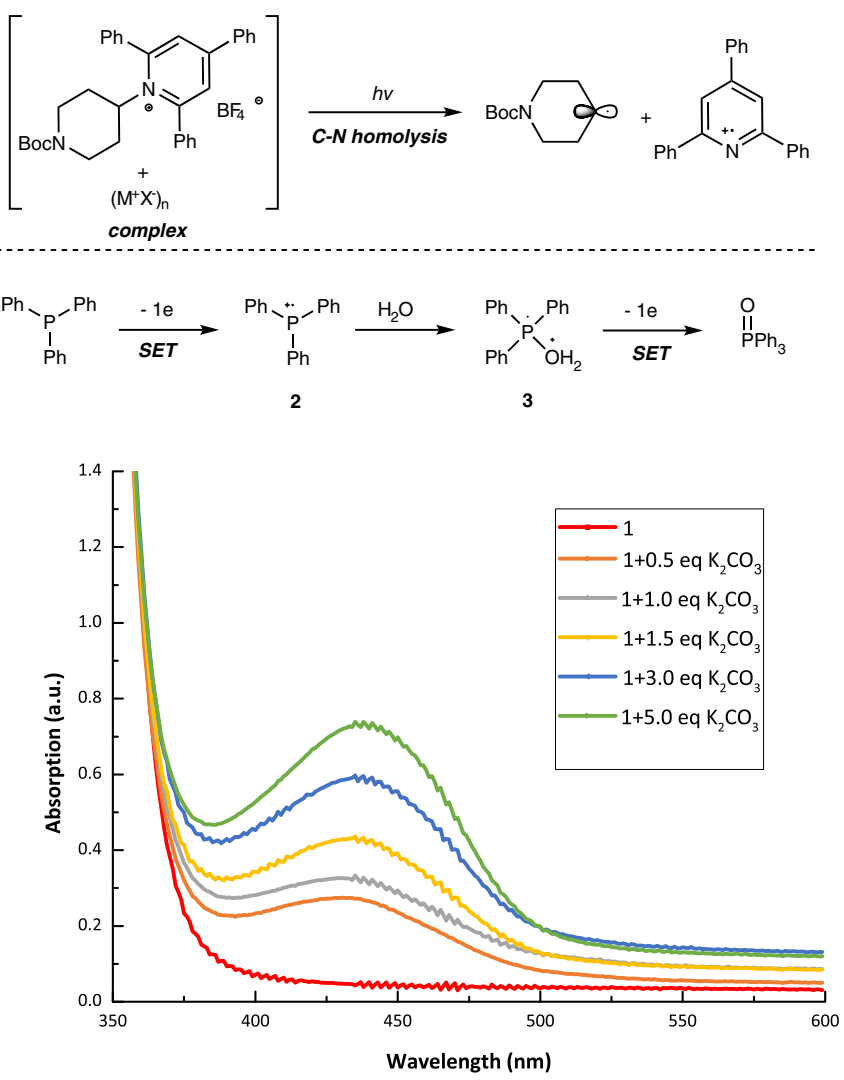

Fig. 1 Design plan. a Photoredox decarboxylative macrocyclization. b UV-Vis absorption spectrum of 1 with ionic compounds. $\mathbf{c}$ Visible light induced ionic compound promoted homolytic fragmentation of pyridinium $\mathrm{C}-\mathrm{N}$ bond. 


\section{Table 1 Control experiments.}

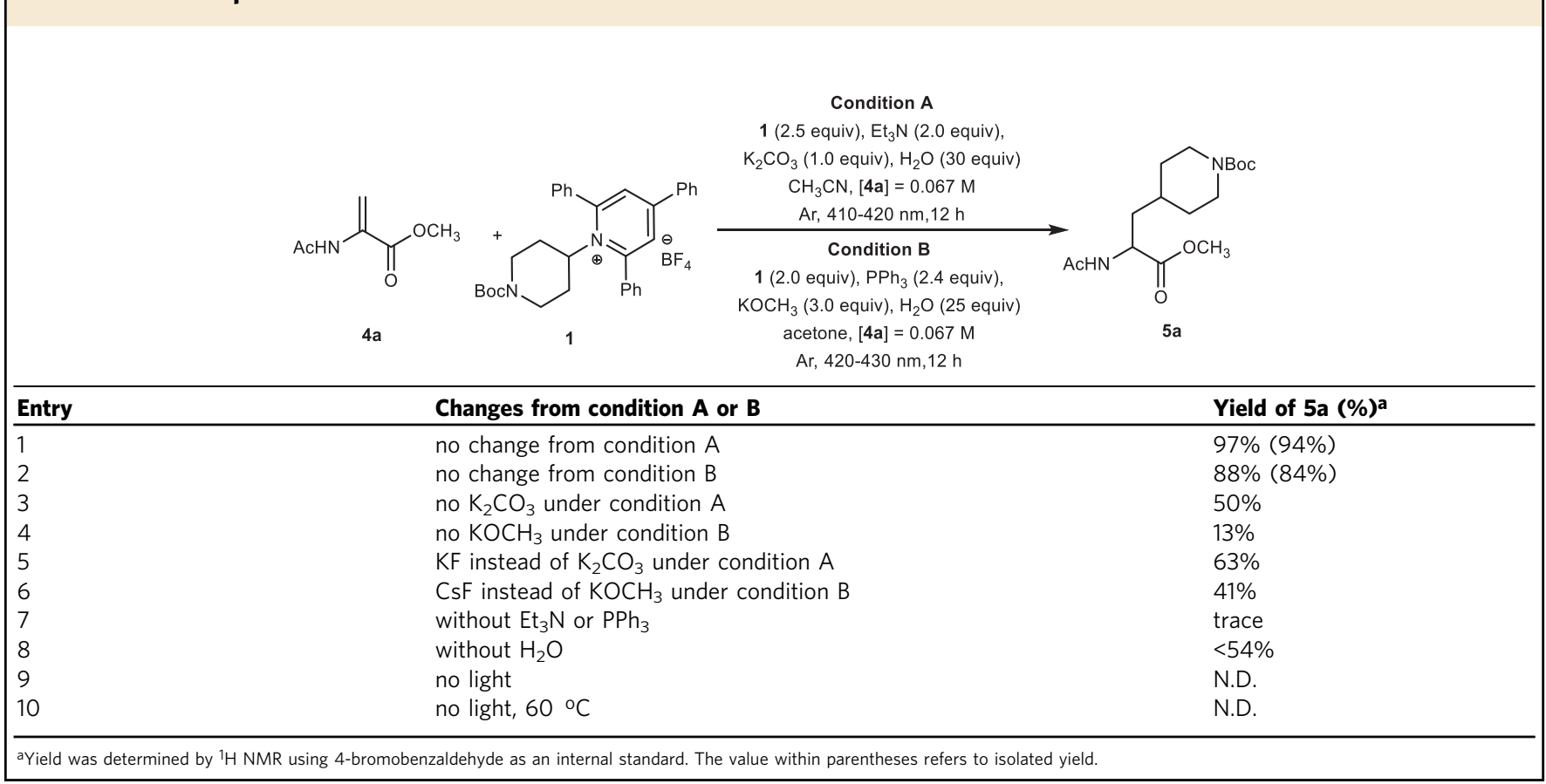

pyridinium 1 is $<400 \mathrm{~nm}$ wavelength. To exploit the photonic energy from visible light (wavelength $>400 \mathrm{~nm}$ ) for cleavage of pyridinium $\mathrm{C}-\mathrm{N}$ bond, photocatalysts ${ }^{48}$ or photoabsorbing EDA complexes are essentially required ${ }^{44,49-53}$. For example, Aggarwal and co-workers recently reported a visible light induced Giesetype alkylation reaction, in which pyridinium and Hantzsch esters in situ formed EDA complex and mediated the photoredox process $^{52}$. Interestingly, in our recent studies, we found that some ionic compounds $\left(\mathrm{M}^{+} \mathrm{X}^{-}\right)$, such as $\mathrm{K}_{2} \mathrm{CO}_{3}, \mathrm{KOCH}_{3}, \mathrm{NaI}, \mathrm{HCl}$, $\mathrm{CF}_{3} \mathrm{CO}_{2} \mathrm{H}$, CsF, etc., could dramatically increase the absorption of 1 in visible light (400-480 nm) region (Fig. 1b, see the "Supplementary information" for details). The loading amount of ionic compound is directly proportional to the light absorption intensity, indicating the key role of ionic additives for increasing the visible light absorption (The reason that ionic additives increasing visible light absorption of Katritzky salt was unclear at this stage. The mechanistic studies and further applications are underway in our lab).

These findings let us wonder whether visible light can be directly used for homolytic alkyl pyridinium (1) C-N bond without assistance of photosensitizers by addition of ionic compounds. If so, upon irradiation, C-N homolysis of $\mathbf{1}$ can promote the release of alkyl radical. Compared with reported EDA complexes triggered SET to alkyl pyridinium, which were highly dependent on a suitable electron donor (e.g., indoles, Hantzsch esters, or aryl amines) to form a light-absorbing aggregator ${ }^{44,49-53}$, these ionic compounds promoted photocatalytic C-N homolysis would unveil more rich photochemistry.

To validate our proposal in Fig. 1c, a suitable single-electron reductant (SER) is required. Tertiary amines are previously widely used as SERs. Besides tertiary amines, we speculated that electronrich tertiary phosphines, such as $\mathrm{PPh}_{3}$, could also be used in our reaction for electron transfer. We assume phosphine could provide one electron to pyridinium radical cation and form a phosphine radical cation 2, which would then react with $\mathrm{H}_{2} \mathrm{O}$ to give the intermediate 3. The latter could act as an SER again by supplying a second electron and yield phosphine oxide. Overall, the proposed photochemical mechanism to generate $\mathrm{C}\left(\mathrm{sp}^{3}\right)$-centered radicals by using phosphine and $\mathrm{H}_{2} \mathrm{O}$ as SER was not realized before ${ }^{54}$.
Investigation of reaction conditions. For our initial explorations (Table 1), we selected N-Ac-Dha methyl ester (4a) $(0.1 \mathrm{mmol})$ as Michael acceptor and N-Boc-protected cyclic pyridinium salt $\mathbf{1}$ as alkyl radical precursor. Most of the tested tertiary alkyl amines and trivalent tertiary phosphines could serve as SER for the reaction, while $\mathrm{Et}_{3} \mathrm{~N}$ (entry 1 ) and $\mathrm{PPh}_{3}$ (entry 2) gave the best results, respectively. Notably, in the case when $\mathrm{PPh}_{3}$ was used, stoichiometric amount of triphenylphosphine oxide $\left(\mathrm{Ph}_{3} \mathrm{PO}\right)$ was formed as a byproduct, indicating that $\mathrm{PPh}_{3}$ and $\mathrm{H}_{2} \mathrm{O}$ were all involved in SET process. 5a was obtained in 50\% yield in the absence of $\mathrm{K}_{2} \mathrm{CO}_{3}$ under condition $\mathrm{A}$, which might be attributed to the formation of the EDA complex between Katritzky salt 1 and $\mathrm{Et}_{3} \mathrm{~N}$ (entry 3$)^{52}$. It is worth noting that the yield of $\mathbf{5 a}$ dramatically increased to $97 \%$ in the presence of $\mathrm{K}_{2} \mathrm{CO}_{3}$ (entry 1 ). The yield of $\mathbf{5 a}$ decreased to $13 \%$ in the absence of $\mathrm{KOCH}_{3}$ under condition $\mathrm{B}$ (entry 4). In addition to $\mathrm{K}_{2} \mathrm{CO}_{3}$ and $\mathrm{KOCH}_{3}$, fluoride additives could also increase the outcome (entries 5 and 6, respectively). Without $\mathrm{Et}_{3} \mathrm{~N}$ or $\mathrm{PPh}_{3}$, only a trace amount of desired product formed (entry 7). The reaction gave diminished yield in the absence of $\mathrm{H}_{2} \mathrm{O}$ (entry 8). We assumed that $\mathrm{H}_{2} \mathrm{O}$ might play two roles in the reaction. One is increasing the solubility of an ionic compound; the other is involving in the SET process when $\mathrm{PPh}_{3}$ is used as an SER reagent (Fig. 1c). Without light irradiation, the reaction did not proceed at room temperature or $60^{\circ} \mathrm{C}$ (entries 9 and 10 , respectively).

Substrate scopes. Having established the optimal reaction conditions (Table 1, entries 1 and 2), we examined a series of alkenes (4b-4l) as shown in Fig. 2a. Similar to Dha, another naturally occurring dehydroamino acid derived alkene, namely dehydrobutyrine, also reacted smoothly to give the corresponding product $\mathbf{5 b}$ in $80 \%$ yield (4:1 d.r.) under condition $\mathrm{A}$ and $76 \%$ yield (4:1 d.r.) under condition B. Other alkenes, such as diethyl fumarate, vinyl sulfone, or dimethyl malonate derived alkene were all compatible in the reaction with good yields $(\mathbf{5 c}-\mathbf{5 e}$, 78-95\%). The Michael acceptors bearing amide groups also worked well under optimal conditions to give the desired products in uniformly good yields $(\mathbf{5 f}-\mathbf{5 j})$. Furthermore, we 

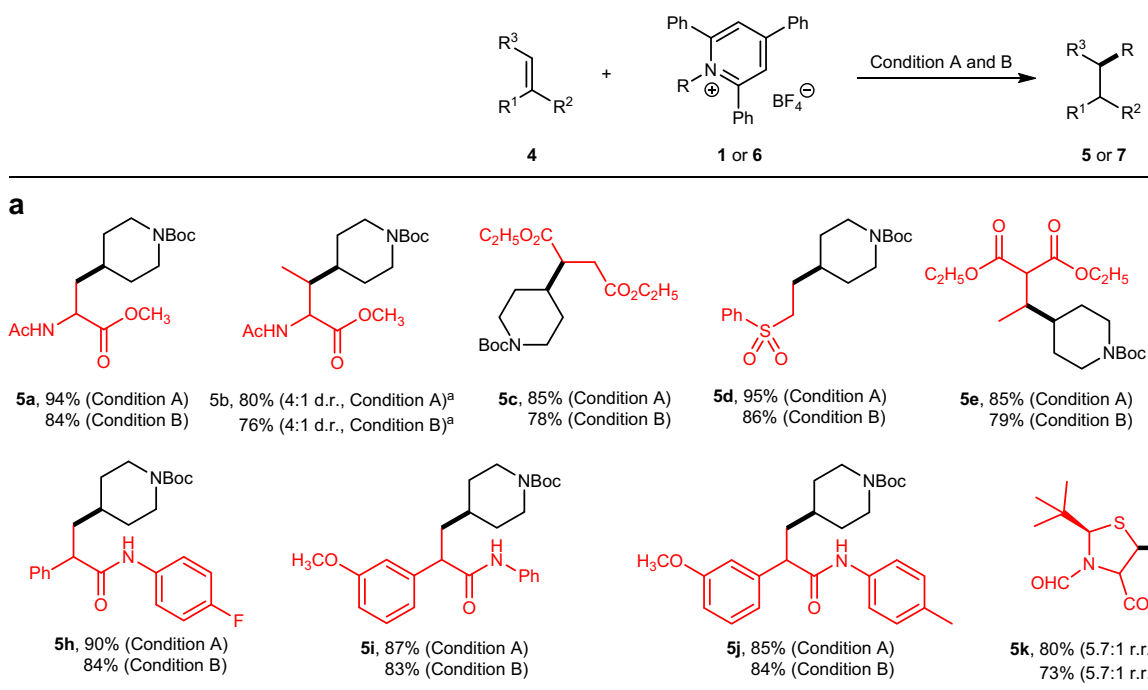<smiles></smiles>
5f, $95 \%$ (Condition A)
92\% (Condition B)

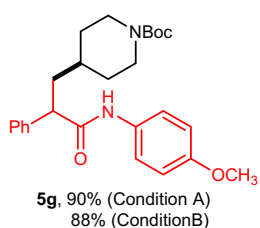

$88 \%$ (ConditionB)

b<smiles>CNC(CC1CCCCC1)C(=O)OC</smiles><smiles>CNC(CC1CCCCCC1)C(=O)OC</smiles><smiles>C=NC(CC(C)C)C(=O)O</smiles><smiles>CNC(CC1Cc2ccccc2C1)C(=O)OC</smiles>

7b, $90 \%$ (Condition A) $\quad 7 \mathbf{c}, 78 \%$ (Condition A) $75 \%$ (Condition) 1 , $82 \%$ (Condition A) $76 \%$ (Condition B)<smiles>CNC(CC1CCC(F)(F)CC1)C(=O)OC</smiles>

7k, $75 \%$ (Condition A) $71 \%$ (Condition B)<smiles>CNC(CC(C)CCc1ccccc1)C(=O)OC</smiles><smiles>CC(=O)OC1C(C2CCN(S(=O)(=O)O)CC2)SC(C(C)(C)C)N1C=O</smiles>

5k, $80 \%(5.7: 1 \text { r.r., Condition A })^{\mathrm{a}}$ $73 \%(5.7: 1 \text { r.r., Condition B })^{a}$

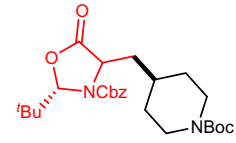

5l, $95 \%$ ( $>20: 1$ d.r., Condition $A)^{a}$ $89 \%$ ( > 20:1 d.r., Condition B)<smiles>CCOC(=O)NC(CCC(=O)OC)C(=O)OC</smiles>

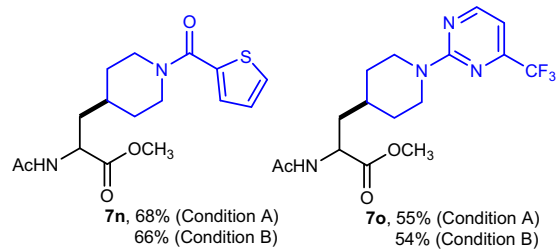

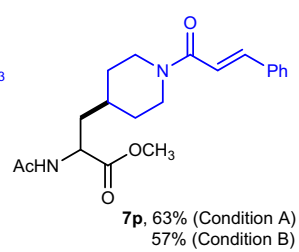<smiles>C#CCOC(=O)C1CCC(CC(NC(C)=O)C(=O)OC)CC1</smiles><smiles>C=C(OC)C(CC(C)C1CCCCC1)NC</smiles><smiles>CC(=O)c1ccccc1</smiles>

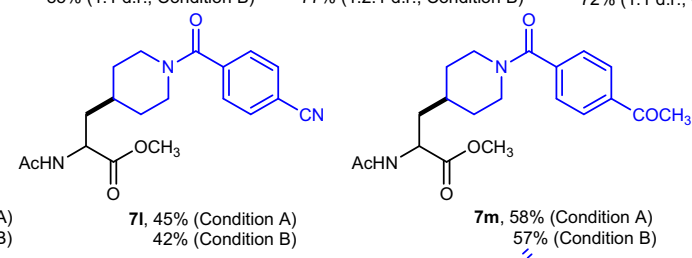

(1)

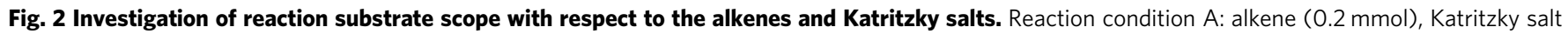

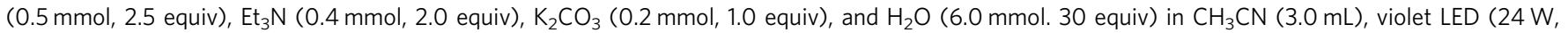

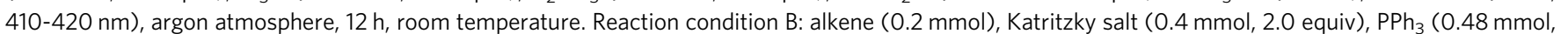

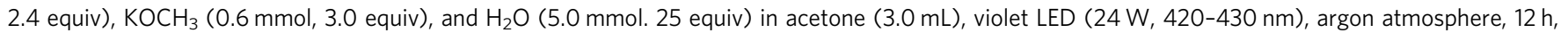

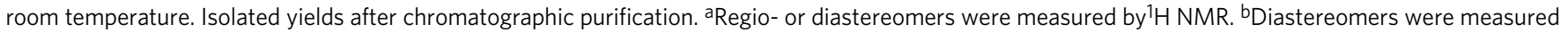
by HPLC. a Substrates with alkenes (Condition A and B). b Substrates with Katritzky salts (Condition A and Condition B).

expanded the reaction scope to $\beta$-thiolated amino acid derivative (4k) which was readily prepared from $L$-cysteine and dehydroalanine derived Karady-Beckwith alkene (41). The corresponding hydroalkylation products $\mathbf{5 k}$ and $\mathbf{5 l}$ were obtained in high yields and good r.r. (rotamers mixture ratio) ${ }^{55}$ or d.r.

Subsequently, we shifted our attention to the scope of Katritzky salts for the synthesis of unnatural $\alpha$-amino acids using a series of secondary alkyl substituted pyridinium (Fig. 2b). Uniformly good yields were obtained (7a-7h, up to $92 \%)$. Importantly, this reaction could be extended to glycine derived Katritzky salt $(\mathbf{7 h}$, 92 and 85\%), which provided the possibility for deaminative $\mathrm{N}$-terminal macrocyclization of the linear peptide backbone. Furthermore, more complex pyridinium radical precursors bearing various functional groups and structural motifs were tested under condition $\mathrm{A}$ and $\mathrm{B}$, which provided corresponding products $7 \mathbf{i}-7 \mathbf{r}$ in moderate to excellent yields. Unfortunately, unactivated primary alkyl substrates had failed to give the desired hydroalkylation products (When the unactivated primary alkyl substrate was used in the reaction, significant amounts of byproduct from radical-radical coupling of primary alkyl dihydropyridine radical with unactivated primary alkyl radical was obtained. See supplementary information for details.).

Next, a variety of Dha containing peptides was prepared to test the functional group tolerance of this reaction with various amino acid residues incorporated. To our delight, peptides bearing glycine, proline, leucine, tryptophan, phenylalanine, or tyrosine units were able to participate in the deaminative conjugation to furnish the desired adducts in yields between 76 and $95 \%$ with 


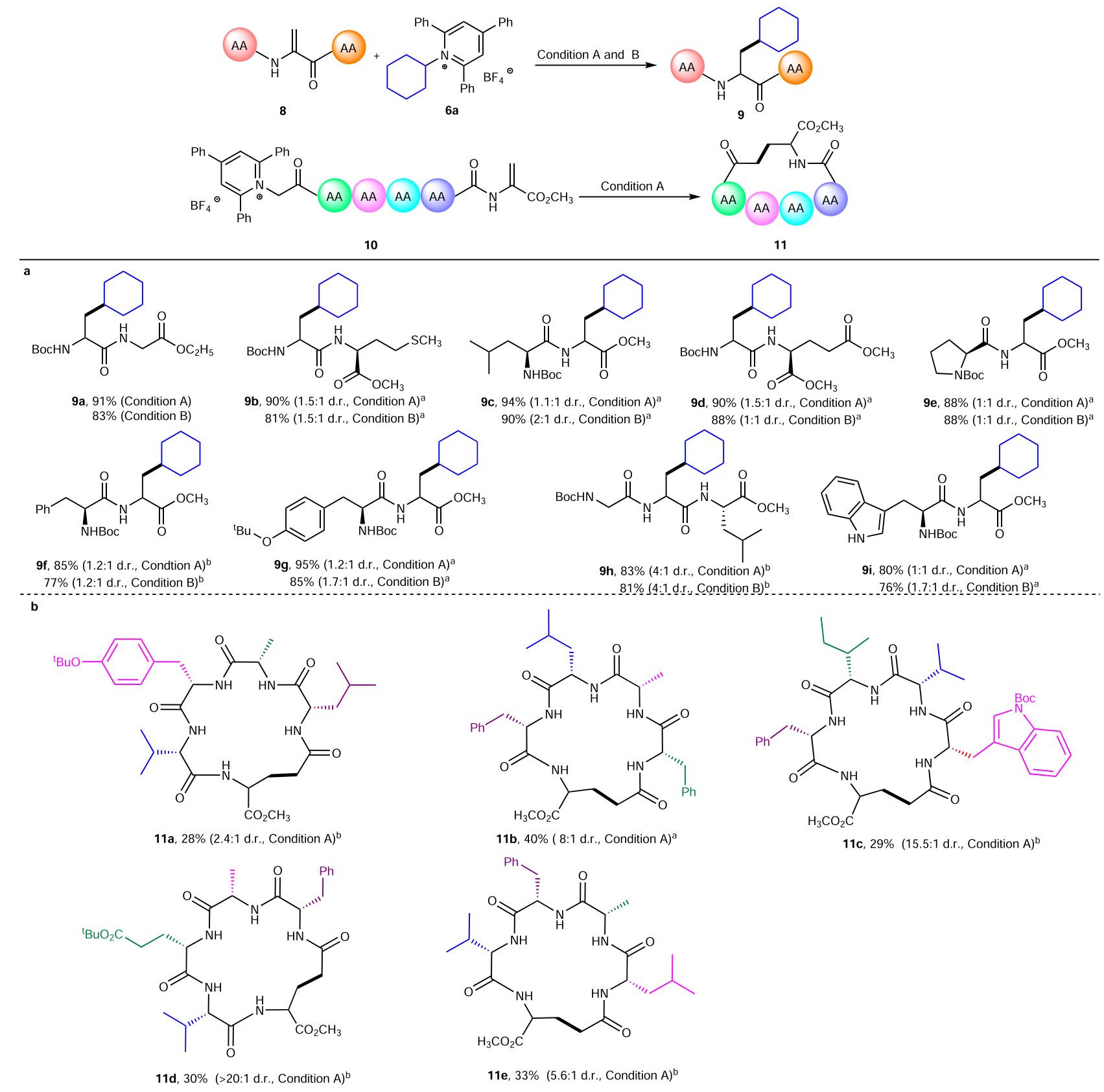

Fig. 3 Modification and macrocyclization of peptides. a Diastereomers were measured by ${ }^{1} \mathrm{H}$ NMR. bDiastereomers were measured by HPLC. a Isolated yield on $0.2 \mathrm{mmol}$ scale (condition $\mathrm{A}$ and condition B). $\mathbf{b}$ For 11a and 11c-11e, isolated yields on $0.02 \mathrm{mmol}$ under condition $\mathrm{A}$; for 11b, isolated yield on $0.05 \mathrm{mmol}$ under condition A.

other amino acid residues untouched (Fig. 3a, 9a-9i). Based on excellent performance on modification of peptides, we turned our attention to deaminative $\mathrm{N}$-terminals macrocyclization of linear peptides. As shown in Fig. 3b, a series of peptides that incorporate a structurally diverse set of amino acids can be successfully cyclized using this deaminative method (11a-11e, 28-40\% isolated yields after HPLC purifications). Regrettably, the attempt to macrocyclize Dha contained peptide "on resin" during solidphase peptide synthesis procedure has failed.

Mechanistic studies. To gain some detailed information for the reaction, a series of mechanistic studies were carried out (see Supplementary information for details). As shown in Fig. 4a, radical trapping experiments indicated that the combination of ionic compounds (such as $\mathrm{K}_{2} \mathrm{CO}_{3}, \mathrm{KOCH}_{3}$, and $\mathrm{CsF}$ ) and pyridinium were able to harness photonic energy from visible light and promoted C-N homolysis of Katritzky salt to generate an alkyl radical. In isotope tracking experiments (Fig. $4 \mathrm{~b}, \mathrm{c}$ ), when $\mathrm{D}_{2} \mathrm{O}$ was used instead of $\mathrm{H}_{2} \mathrm{O}$ under Condition $\mathrm{A}$ and $\mathrm{B}$, deuterated product $\mathbf{5 a}-\mathbf{D}$ and $7 \mathbf{a}-\mathbf{D}$ were obtained in 86 and $34 \%$ yield, respectively, revealing that $\mathrm{H}_{2} \mathrm{O}$ acted as hydrogen atom source to provide an $\mathrm{H}^{+}$for the hydroalkylation process. Furthermore, stoichiometric amount of triphenylphosphine oxide $\left(\mathrm{Ph}_{3} \mathrm{PO}\right)$ was formed as the byproduct, which suggested that $\mathrm{PPh}_{3}$ could possibly provide two electrons in a stepwise way during the SET process (Fig. 4b). The UV-Vis absorption of individual reagents or mixtures were shown in Fig. $4 \mathrm{~d}$. None of $\mathrm{Et}_{3} \mathrm{~N}, \mathrm{PPh}_{3}$, pyridinium (1), or the mixture of $\left[\mathrm{PPh}_{3}+\mathbf{1}\right]$ showed significant 
$\mathbf{1}+$ ionic compound $+\underset{\substack{\text { (3.0 equiv) } \\ \mathrm{Tr}, 420-430 \mathrm{~nm}}}{\text { acetone }}$

ionic compound $=\mathrm{KOCH}_{3}, \mathrm{~K}_{2} \mathrm{CO}_{3}$ and $\mathrm{CsF}$ etc.

detected by HRMS

b

$\underset{\mathrm{O}}{\mathrm{AcHN}} \underset{\prod^{-}}{\mathrm{OCH}_{3}}+\mathbf{6 a} \underset{\mathrm{D}_{2} \mathrm{O} \text { (25 equiv) }}{\stackrel{\text { Condition } \mathrm{B}}{\longrightarrow}}$

$4 a$

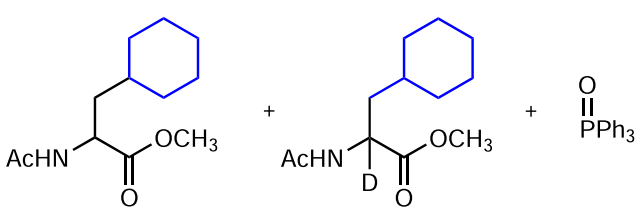

7a, $46 \%$

7a-D, $34 \%$

c

$\underset{\mathrm{O}}{\mathrm{AcHN}} \prod_{\mathrm{D}_{2} \mathrm{O} \text { (30 equiv) }}^{\mathrm{OCH}_{3}}$

$4 a$<smiles>COC(=O)C(CC1CCN(C(C)(C)C)CC1)NC(C)=O</smiles>

5 a, $5 \%$<smiles>[2H]C(CC1CCN(C(C)(C)C)CC1)(NC(C)C)C(=O)OC</smiles>

5a-D, $86 \%$

d
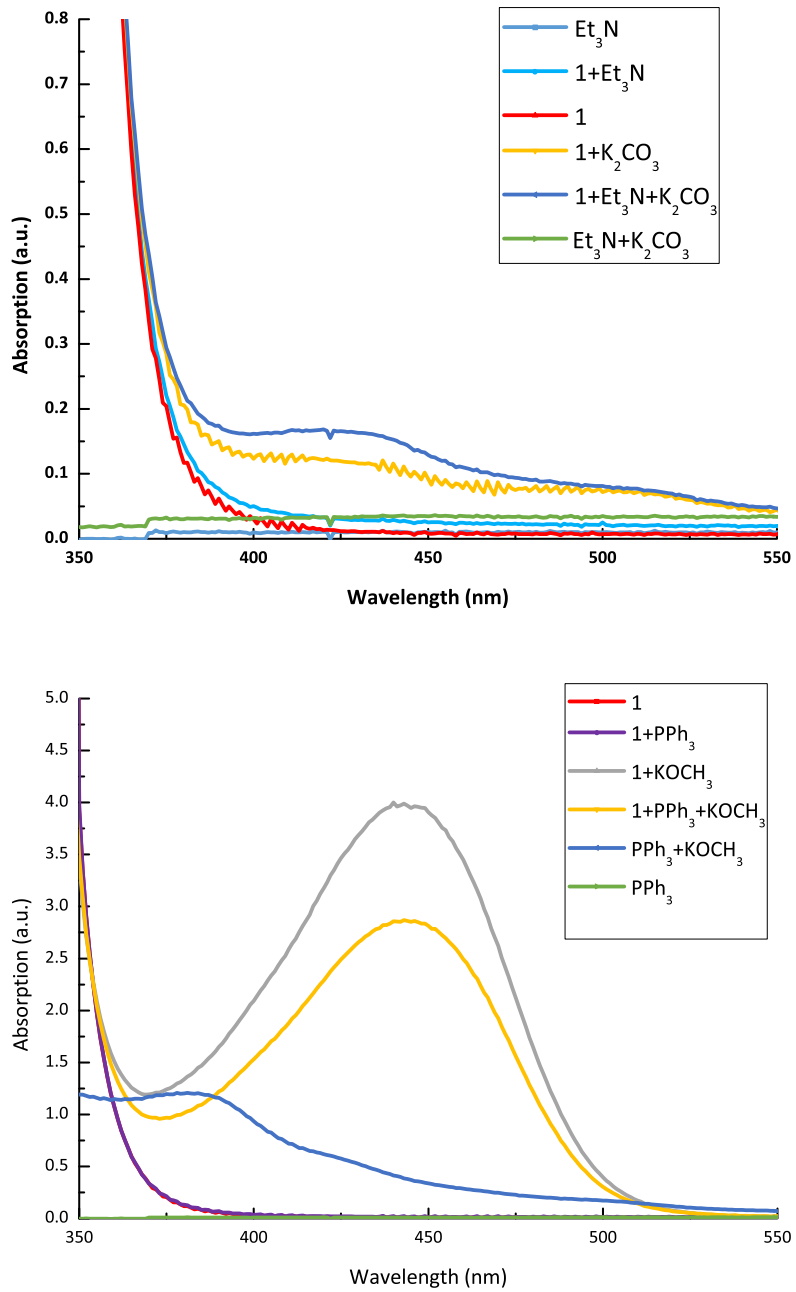

Fig. 4 Mechanistic studies. a Radical trapping experiments. b Isotope tracking experiments of Condition B. c Isotope tracking experiments of Condition A. d Analysis of UV-Vis absorption spectra. 


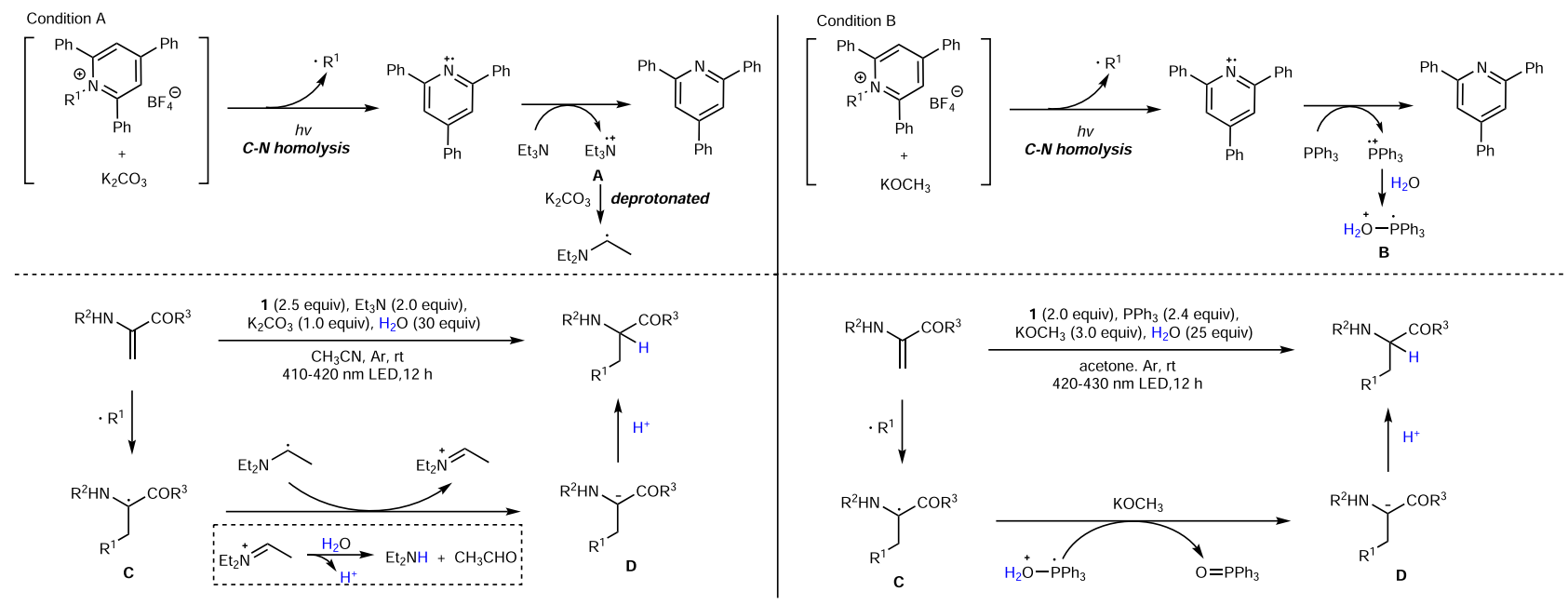

Fig. 5 Proposed mechanism. Visible-light-mediated catalyst-free synthesis of unnatural $\alpha$-amino acids.

absorption over $400 \mathrm{~nm}$. However, basic ionic compounds, namely $\mathrm{K}_{2} \mathrm{CO}_{3}$ and $\mathrm{KOCH}_{3}$, could dramatically increase the absorption of pyridinium (1) in the visible light region, respectively. Interestingly, the combination $\left[\mathrm{Et}_{3} \mathrm{~N}+\mathbf{1}\right]$ showed a slight bathochromic shift, which might be due to the formation of EDA complex between 1 and $\mathrm{Et}_{3} \mathrm{~N}^{52}$. Although this EDA complex could possibly mediate the alkylation process (Table 1, entry 3 ), the yield was significantly lower than for $\mathrm{K}_{2} \mathrm{CO}_{3}$ promoted reaction (50\% vs 97\%). Some ionic compounds, such as $\mathrm{Cs}_{2} \mathrm{CO}_{3}$, $\mathrm{K}_{3} \mathrm{PO}_{4}$, and $\mathrm{NaOCH}_{3}$, provide higher levels of visible light absorption; however, only moderate yields were obtained (Table S3 and Fig. S8). The use of $\mathrm{KBF}_{4}$ and $\mathrm{NaBF}_{4}$ as ionic additives did not give any desired product, which indicated that $\mathrm{BF}_{4}{ }^{-}$counter anion in Katritzky salt was not crucial for the transformation (Table S3, Table S13, and Fig. S8).

On the basis of these preliminary results, a possible mechanism is proposed (Fig. 5) (Although the mechanistic investigations suggested that a visible light promoted C-N homolysis of Katritzky salts in the presence of ionic compounds is highly possible in our reaction, the EDA complex pathway cannot be completely ruled out at this stage. See supplementary information for details.). Initially, C-N homolysis of Katritzky salt occurred in the presence of basic ionic compounds under visible light irradiation, followed by the formation of an alkyl radical $\left(\cdot \mathrm{R}^{1}\right)$ and pyridinium radical cation. $\mathrm{Et}_{3} \mathrm{~N}\left(\mathrm{PPh}_{3}\right)$ was oxidized to nitrogen radical cation $\mathbf{A}^{52}$ (phosphine radical cation) with the formation of 2,4,6-triphenylpyridine. Notably, under condition $\mathbf{A}$, nitrogen radical cation $\mathbf{A}$ is deprotonated to yield $\alpha$-amino radical, and under condition $B$, phosphine radical cation reacted with $\mathrm{H}_{2} \mathrm{O}$ to give intermediate $\mathbf{B}^{54}$. Radical addition of $\cdot \mathrm{R}^{1}$ to Michael acceptor 4 gives radical intermediate $C$. According to the previous report ${ }^{56}$, under condition $\mathrm{A}$, intermediate $\mathbf{C}$ was reduced by $\alpha$-amino radical to give the carbon anion species $\mathbf{D}$ and an immonium ion. Subsequently, the hydrolysis of immonium ion promoted the generation of diethylamine and acetaldehyde, followed by the release of a proton. Under condition $\mathrm{B}$, intermediate $\mathrm{C}$ was reduced by $\mathbf{B}$ to form a carbon anion species $\mathbf{D}$ alone with the formation of triphenylphosphine oxide. The final protonation of D provided our desired deaminative hydroalkylation product. In condition $\mathrm{B}, \mathrm{PPh}_{3}$ served as the single-electron reductant and provided two electrons in a stepwise way.

\section{Discussion}

In summary, we report ionic compounds promoted homolytic cleavage of pyridinium $\mathrm{C}-\mathrm{N}$ bond by exploiting the photonic energy from visible light. This finding was successfully applied in deaminative hydroalkylation of a series of alkenes including naturally occurring Dha, which provided an efficient way to prepare $\beta$-alkyl substituted UAAs under mild and catalyst-free conditions. Importantly, by using this protocol, the deaminative cyclization of peptide backbone N-terminals was realized. Furthermore, the use of $\mathrm{Et}_{3} \mathrm{~N}$ or $\mathrm{PPh}_{3}$ as reductants and $\mathrm{H}_{2} \mathrm{O}$ as hydrogen atom source is a significantly practical advantage. Further investigating the mechanism of ionic compounds improved visible light absorption of pyridinium and other synthetic applications are currently underway and will be reported in due course.

\section{Methods}

General procedure of condition A. To an oven-dried $10 \mathrm{~mL}$ quartz test tube with a stirring bar was added alkene $(0.2 \mathrm{mmol})$, alkyl pyridinium salt $(0.5 \mathrm{mmol}, 2.5$ equiv), $\mathrm{Et}_{3} \mathrm{~N}$ (0.4 mmol, 2 equiv), and $\mathrm{K}_{2} \mathrm{CO}_{3}(0.2 \mathrm{mmol}, 1$ equiv). Then, the air was withdrawn and backfilled with $\mathrm{Ar}$ (three times). $\mathrm{CH}_{3} \mathrm{CN}(3 \mathrm{~mL})$ and $\mathrm{H}_{2} \mathrm{O}(6 \mathrm{mmol}$, 30 equiv) were added. The mixture was transferred to a violet LED photoreactor (24-W, 410-420 nm), where it was irradiated for $12 \mathrm{~h}$. Then, the reaction was quenched with water $(5 \mathrm{~mL})$, extracted with ethyl acetate, washed with brine, dried over anhydrous sodium sulfate, concentrated in vacuo, and purified by column chromatography (hexane/acetone) to afford the product.

General procedure of condition B. To an oven-dried $10 \mathrm{~mL}$ quartz test tube with a stirring bar was added alkene $(0.2 \mathrm{mmol})$, alkyl pyridinium salt $(0.4 \mathrm{mmol}, 2.0$ equiv), $\mathrm{PPh}_{3}$ ( $0.48 \mathrm{mmol}, 2.4$ equiv), and $\mathrm{KOCH}_{3}(0.6 \mathrm{mmol}, 3.0$ equiv). Then, the air was withdrawn and backfilled with $\mathrm{Ar}$ (three times). Acetone $(3 \mathrm{~mL})$ and $\mathrm{H}_{2} \mathrm{O}$ ( 5 mmol, 25 equiv) were added. The mixture was transferred to a violet LED photoreactor (24-W, 420-430 nm), where it was irradiated for $12 \mathrm{~h}$. Then, the reaction was quenched with water $(5 \mathrm{~mL})$, extracted with ethyl acetate, washed with brine, dried over anhydrous sodium sulfate, concentrated in vacuo, and purified by column chromatography (hexane/acetone) to afford the product.

\section{Data availability}

The authors declare that the data supporting the findings of this study, including experimental details and compound characterization, are available within the article and its Supplementary information file. All data are available from the corresponding author upon request.

Received: 18 April 2021; Accepted: 14 October 2021; Published online: 25 November 2021

\section{References}

1. Lau, J. L. \& Dunn, M. K. Therapeutic peptide: historical perspectives, current development trends, and future directions. Bioorg. Med. Chem. 26, 2700-2707 (2018).

2. Kaspar, A. A. \& Reichert, J. M. Future direction for peptide therapeutics development. Drug Discov. Today 18, 807-817 (2013). 
3. Qvit, N., Rubin, S. J. S., Urban, T. J., Mochly-Rosen, D. \& Gross, E. R. Peptidomimetic therapeutics: scientific approaches and opportunities. Drug Discov. Today 22, 454-462 (2017).

4. Gentilucci, L., De Marco, R. \& Cerisoli, L. Chemical modifications designed to improve peptide stability: incorporation of non-natural amino acids, pseudopeptide bonds, and cyclization. Curr. Pharm. Des. 16, 3185-3203 (2010).

5. Shaw, M. H., Twilton, J. \& MacMillan, D. W. C. Photoredox catalysis in organic chemistry. J. Org. Chem. 81, 6898-6926 (2016).

6. Easton, C. J. Free-radical reactions in the synthesis of $\alpha$-amino acids and derivatives. Chem. Rev. 97, 53-82 (1997).

7. Bottecchia, C. \& Noël, T. Photocatalytic modification of amino acids, peptides, and proteins. Chem. Eur. J. 25, 26-42 (2019).

8. Liu, J.-Q., Shatskiy, A., Matsuura, B. S. \& Kärkäs, M. D. Recent advances in photoredox catalysis enabled functionalization of $\alpha$-amino acids and peptides: concepts, strategies and mechanisms. Synthesis 51, 2759-2791 (2019).

9. Larionov, V. A., Stoletova, N. V. \& Maleev, V. I. Advances in asymmetric amino acid synthesis enabled by radical chemistry. Adv. Syn. Catal. 362, 4325-4367 (2020).

10. King, T. A., Kandemir, J. M., Walsh, S. J. \& Spring, D. R. Photocatalytic methods for amino acid modification. Chem. Soc. Rev. 50, 39-57 (2021).

11. Troyano, F. J. A., Merkens, K., Anwar, K. \& Gómez-Suárez, A. Radical-based synthesis and modification of amino acids. Angew. Chem. Int. Ed. 60, 1098-1115 (2021).

12. Kärkäs, M. D. \& Shatskiy, A. Photoredox-enabled decarboxylative synthesis of unnatural $\alpha$-amino acids. Synlett https://doi.org/10.1055/a-1499-8679 (2021).

13. Siodłak, D. $\alpha, \beta$-Dehydroamino acids in naturally occurring peptides. Amino Acids 47, 1-17 (2015).

14. Repka, L. M., Chekan, J. R., Nair, S. K. \& van der. Donk, W. A. Mechanistic understanding of lanthipeptide biosynthetic enzymes. Chem. Rev. 117, 5457-5520 (2017).

15. Strumeyer, D. H., White, W. N. \& Koshland, D. E. Jr. Role of serine in chymotrypsin action-conversion of active serine to dehydroalanine. Proc. Natl Acad. Sci. U. S. A. 50, 931-935 (1963).

16. Bernardes, G. J. L., Chalker, J. M., Errey, J. C. \& Davis, B. G. Facile conversion of cysteine and alkyl cysteines to dehydroalanine on protein surfaces: versatile and switchable access to functionalized proteins. J. Am. Chem. Soc. 130, 5052-5053 (2008).

17. Navarre, L., Darses, S. \& Genet, J.-P. Tandem 1,4-addition/enantioselective protonation catalyzed by rhodium complexes: efficient access to $\alpha$-amino acids. Angew. Chem. Int. Ed. 43, 719-723 (2004)

18. Aycock, R. A., Vogt, D. B. \& Jui, N. T. A practical and scalable system for heteroaryl amino acid synthesis. Chem. Sci. 8, 7998-8003 (2017).

19. Suárez, R. M., Pérez Sestelo, J. \& Sarandeses, L. A. Practical and efficient enantioselective synthesis of $\alpha$-amino acids in aqueous media. Org. Biomol. Chem. 2, 3584-3587 (2004).

20. Larionov, V. A. et al. A general synthesis of unnatural $\alpha$-amino acids by ironcatalysed olefin-olefin coupling via generated radicals. Org. Chem. Front. 6 , 1094-1099 (2019).

21. Huang, T.-S. \& Li, C.-J. Novel synthesis of $\alpha$-amino acids via catalysis in air and water. Org. Lett. 3, 2037-2039 (2001).

22. Kieffer, M. E., Repka, L. M. \& Reisman, S. E. Enantioselective synthesis of tryptophan derivatives by a tandem Friedel-Crafts conjugate addition/ asymmetric protonation reaction. J. Am. Chem. Soc. 134, 5131-5137 (2012).

23. Shah, A. A., Kelly, M. J. III \& Perkins, J. J. Access to unnatural $\alpha$-amino acids via visible-light-mediated decarboxylative conjugate addition to dehydroalanine. Org. Lett. 22, 2196-2200 (2020).

24. Zhang, O. \& Schubert, J. W. Derivatization of amino acids and peptides via photoredox-mediated conjugate addition. J. Org. Chem. 85, 6225-6232 (2020).

25. Merkens, K., Troyano, F. J. A., Djossou, J. \& Gómez-Suárez, A. Synthesis of unnatural $\alpha$-amino acid derivatives via light mediated radical decarboxylative processes. Adv. Synth. Catal. 362, 2354-2359 (2020).

26. Aycock, R. A., Pratt, C. J. \& Jui, N. T. Aminoalkyl radicals as powerful intermediates for the synthesis of unnatural amino acids and peptides. ACS Catal. 8, 9115-9119 (2018).

27. Sim, J., Campbell, M. W. \& Molander, G. A. Synthesis of a-fluoro-a-amino acid derivatives via photoredox catalyzed carbofluorination. ACS Catal. 9 , 1558-1563 (2019).

28. Brandhofer, T. \& Mancheño, O. G. Versatile Ru-photoredox-catalyzed functionalization of dehydro-amino acids and peptides. ChemCatChem 11, 3797-3801 (2019).

29. Reich, D., Trowbridge, A. \& Gaunt, M. J. Rapid syntheses of (-)-FR901483 and (+)-TAN1251C enabled by complexity-generating photocatalytic olefin hydroaminoalkylation. Angew. Chem. Int. Ed. 59, 2256-2261 (2020).

30. Ji, P. et al. Synthesis of enantioenriched $\alpha$-deuterated $\alpha$-amino acids enabled by an organophotocatalytic radical approach. Org. Lett. 22, 1557-1562 (2020).

31. Wang, X., Chen, Y., Song, H., Liu, Y. \& Wang, Q. Synthesis of unnatural $\alpha$-amino acids via photoinduced decatungstate-catalyzed Giese reactions of aldehydes. Org. Lett. 23, 2199-2204 (2021).
32. Dai, Z.-Y., Nong, Z.-S., Song, S. \& Wang, P. S. Asymmetric photocatalytic C( $\left.\mathrm{sp}^{3}\right)$ $\mathrm{H}$ bond addition to $\alpha$-substituted acrylates. Org. Lett. 23, 3157-3161 (2021).

33. van Lier, R. C. W., de Bruijn, A. D. \& Roelfes, G. A water-soluble iridium photocatalyst for chemical modification of dehydroalanines in peptides and proteins. Chem. Eur. J. 27, 1430-1437 (2021)

34. de Vries, R. H., Viel, J. H., Kuipers, O. P. \& Roelfes, G. Rapid and selective chemical editing of ribosomally synthesized and post-translationally modified peptides (RiPPs) via CuII-catalyzed $\beta$-borylation of dehydroamino acids. Angew. Chem. Int. Ed. 60, 3946-3950 (2021).

35. Rivera, D. G., Ojeda-Carralero, G. M., Reguera, L., Eycken \& van der, E. V. Peptide macrocyclization by transition metal catalysis. Chem. Soc. Rev. 49, 2039-2059 (2020).

36. Malins, L. R. Peptide modification and cyclization via transition-metal catalysis. Curr. Opin. Chem. Biol. 46, 25-32 (2018).

37. Wang, W., Lorion, M. M., Shah, J., Kapdi, A. R., \& Ackermann, L. Late-stage peptide diversification by position-selective C-H activation. Angew. Chem. Int. Ed. 57, 14700-14717 (2018)

38. Noisier, A. F. M. \& Brimble, M. A. C-H functionalization in the synthesis of amino acids and peptides. Chem. Rev. 114, 8775-8806 (2014).

39. Raynal, L., Rose, N. C., Donald, J. R., \& Spicer, C. D. Photochemical methods for peptide macrocyclisation. Chem. Eur. J. 27, 69-88 (2021).

40. McCarver, S. J. et al. Decarboxylative peptide macrocyclization through photoredox catalysis. Angew. Chem. Int. Ed. 56, 728-732 (2017).

41. Chu, L., Ohta, C., Zuo, Z., \& MacMillan, D. W. C. Carboxylic acids as a traceless activation group for conjugate additions: a three-step synthesis of ( \pm )-pregabalin. J. Am. Chem. Soc. 136, 10886-10889 (2014).

42. Correia, J. T. M. et al. Photoinduced deaminative strategies: Katritzky salts as alkyl radical precursors. Chem. Commun. 56, 503-514 (2020).

43. Ashley, M. A. \& Rovis, T. Photoredox-catalyzed deaminative alkylation via C-N bond activation of primary amines. J. Am. Chem. Soc. 142, 18310-18316 (2020).

44. Wang, C. et al. Visible-light-promoted $\mathrm{C}\left(\mathrm{sp}^{3}\right)$ - $\mathrm{H}$ alkylation by intermolecular charge transfer: preparation of unnatural $\alpha$-amino acids and late-stage modification of peptides. Angew. Chem. Int. Ed. 59, 7462-7466 (2020)

45. Wang, C. et al. Visible-light-driven, copper-catalyzed decarboxylative $\mathrm{C}\left(\mathrm{sp}^{3}\right)-\mathrm{H}$ alkylation of glycine and peptides. Angew. Chem. Int. Ed. 57, 15841-15846 (2018)

46. Xue, $H$. et al. Photo-induced preparation of unnatural $\alpha$-amino acids: synthesis and characterization of novel $\mathrm{Leu}^{5}$-enkephalin analogues. Org. Chem. Front. 7, 2426-2431 (2020).

47. Lorance, E. D., Kramer, W. H. \& Gould, I. R. Kinetics of reductive N-O bond fragmentation: the role of a conical intersection. J. Am. Chem. Soc. 124 15225-15238 (2002)

48. Rössler, S. L. et al. Pyridinium salts as redox-active functional group transfer reagents. Angew. Chem. Int. Ed. 59, 9264-9280 (2020)

49. Sandfort, F., Strieth-Kalthoff, F., Klauck, F. J. R., James, M. J. \& Glorius, F. Deaminative borylation of aliphatic amines enabled by visible light excitation of an electron-donor-acceptor complex. Chem. Eur. J. 24, 17210-17214 (2018)

50. Wu, J., He, L., Noble, A. \& Aggarwal, V. K. Photoinduced deaminative borylation of alkylamines. J. Am. Chem. Soc. 140, 10700-10704 (2018)

51. James, M. J. et al. Visible-light-mediated charge transfer enables C-C bond formation with traceless acceptor groups. Chem. Eur. J. 25, 8240-8244 (2019),

52. Wu, J., Grant, P. S., Li, X., Noble, A. \& Aggarwal, V. K. Catalyst-free deaminative functionalizations of primary amines via photoinduced singleelectron transfer. Angew. Chem. Int. Ed. 58, 5697-5701 (2019).

53. Crisenza, G. E. M., Mazzarella, D. \& Melchiorre, P. Synthetic methods driven by the photoactivity of electron donor-acceptor complexes. J. Am. Chem. Soc 142, 5461-5476 (2020).

54. Pan, D., Nie, G., Jiang, S., Li, T. \& Jin, Z. Radical reactions promoted by trivalent tertiary phosphines. Org. Chem. Front. 7, 2349-2371 (2020).

55. Yin, H. et al. Stereoselective and divergent construction of $\beta$-thiolated/ selenolated amino acids via photoredox-catalyzed asymmetric Giese reaction. J. Am. Chem. Soc. 142, 14201-14209 (2020).

56. Lewis, F. D., Ho, T.-I. \& Simpson, J. T. Photochemical addition of tertiary amines to stilbene. Stereoelectronic control of tertiary amine oxidation. J. Org. Chem. 46, 1077-1082 (1981).

\section{Acknowledgements}

Supported by the National Natural Science Foundation of China (21971098), Innovation Project of Medicine and Health Science and Technology of Chinese Academy of Medical Sciences (2019-I2M-5-074), and the Funds for Fundamental Research Creative Groups of Gansu Province (20JR5RA310).

\section{Author contributions}

Z.X. conceived the idea and directed the project; Z.X. and C.W. designed the experiments; M.W., C.W., Y.H., H.X., L.L., H.C., X.X., Z.L., X.D., and D.L. performed the experiments; M.W. and C.W. analyzed the data; Z.X. and C.W. wrote the manuscript. 


\section{Competing interests}

The authors declare no competing interests.

\section{Additional information}

Supplementary information The online version contains supplementary material available at https://doi.org/10.1038/s41467-021-27086-x.

Correspondence and requests for materials should be addressed to Zhaoqing $\mathrm{Xu}$.

Peer review information Nature Communications thanks Markus Kärkäs and the other anonymous reviewer(s) for their contribution to the peer review of this work.

Reprints and permission information is available at http://www.nature.com/reprints

Publisher's note Springer Nature remains neutral with regard to jurisdictional claims in published maps and institutional affiliations. (c) (i) Open Access This article is licensed under a Creative Commons Attribution 4.0 International License, which permits use, sharing, adaptation, distribution and reproduction in any medium or format, as long as you give appropriate credit to the original author(s) and the source, provide a link to the Creative Commons license, and indicate if changes were made. The images or other third party material in this article are included in the article's Creative Commons license, unless indicated otherwise in a credit line to the material. If material is not included in the article's Creative Commons license and your intended use is not permitted by statutory regulation or exceeds the permitted use, you will need to obtain permission directly from the copyright holder. To view a copy of this license, visit http://creativecommons.org/ licenses/by/4.0/.

(C) The Author(s) 2021 